\title{
Analisis Fitokimia Metabolit Sekunder Ekstrak Daun dan Buah Solanum blumei Nees ex Blume lokal
}

\section{Secondary Metabolites Phytochemical Analysis of Leaves and Fruit Extract Solanum blumei Nees ex Blume Local}

\author{
1Jurusan Kimia, FMIPA, Universitas Negeri Medan, Medan-Indonesia \\ 2Jurusan Kimia, FMIPA, Universitas Sumatera Utara, Medan-Indonesia \\ 3Pusat Penelitian Bioteknologi, LIPI, Cibinong-Indonesia \\ *Korespondensi: murniatysimorangkir@unimed.ac.id
}

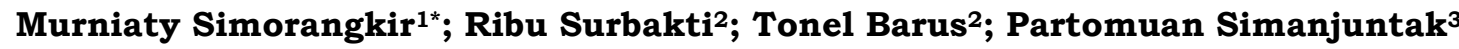

\begin{abstract}
Abstrak: Tanaman ranti hitam (Solanum blumei Nees ex Blume), famili Solanaceae, ditemukan di daerah Karo dan Dairi, secara tradisional digunakan sebagai tanaman obat. Penelitian metabolit sekunder dari ekstrak tanaman $S$. blumei Nees ex Blume lokal bertujuan untuk mengembangkan potensinya sebagai bahan obat. Hasil analisis fitokimia ekstrak S. blumei Nees ex Blume menunjukkan bahwa metabolit sekunder alkaloid, flavonoid, tannin dan saponin lebih banyak terdapat pada ekstrak etanol daun daripada ekstrak etanol buah. Kuinon hanya terdapat pada ekstrak etanol daun. Fenol banyak terdapat pada eksrak etil asetat daun dan buah.Steroid dan triterpenoid banyak terdapat pada ekstrak n-heksana dan etil asetat daun dan buah serta dalam ekstrak etanol daun. Rendemen ekstrak nheksana, etil asetat dan etanol daun S. blumei Nees ex Blume berturut-turut adalah 1,76 \%; 3,17 \% dan 9,95\% (b/b). Rendemen ekstrak n-heksana, etil asetat dan etanol buah $S$. blumei Nees ex Blume berturut-turut adalah 1,21\%; $2,50 \%$ dan $4,09 \%(b / b)$
\end{abstract}

Kata kunci: fitokimia, Indonesia, ranti hitam (Solanum blumei Nees ex Blume), tanaman obat

\begin{abstract}
Ranti hitam plant (Solanum blumei Nees ex Blume), Solanaceae family is found in Karo and Dairi, traditionally used as a medicinal plant. The results of phytochemical analysis of extract of S. blumei Nees ex Blume shows that secondary metabolites alkaloids, flavonoids, tannins and saponin are more numerous in the ethanol extract of the leaves than the ethanol extract of the fruit. Quinone is only found in the ethanol extract of the leaves. Phenol is widely available on the ethyl acetate extracts of leaves and fruit.Steroids and triterpenoids are abundant in n-hexane extract and ethyl acetate leaves and fruit as well as the ethanol extract of the leaves. The yield of extract $n$-hexane, ethyl acetate and ethanol blumei leaves $S$. Nees ex Blume respectively are 1.76\%; 3.17\% and 9.95\% (w/w). The yield of extract n-hexane, ethyl acetate and ethanol fruit S. blumei Nees ex Blume respectively are 1.21\%; $2.50 \%$ and $4.09 \%(w / w)$.
\end{abstract}

Keywords: phytochemicals, Indonesian, ranti hitam (Solanum blumei Nees ex Blume), medicinal plant

\section{PENDAHULUAN}

Tanaman ranti hitam atau leuh mbiring (nama daerah) banyak ditemukan di daerah Dairi dan Karo, khususnya desa Kuta Nangka, Kecamatan Tanah Pinem, Kabupaten Dairi. Ranti hitam telah sering digunakan oleh masyarakat sebagai tanaman obat tradisional (etnomedikal) antara lain obat sakit pinggang, telinga berair, obat demam, obat sakit perut (langgum=bahasa Karo) dan lain-lain, selain sebagai sayur. Tanaman ranti hitam ini termasuk ke dalam golongan semak, tumbuh menjalar. Memiliki akar tunggang dengan warna putih kecoklatan. Batang kecil, berbentuk bulat, lunak, dan berwarna hitam.Berdaun tunggal, bulat melebar, dan tersebar dengan panjang 7-9 cm; lebar 4-6 cm. Pangkal dan ujung daun meruncing dengan tepi rata.Pertulangan daun menyirip. Daun mempunyai tangkai dengan panjang $\pm 3,5 \mathrm{~cm}$ dan berwarna hijau. Bunga berupa bunga majemuk dengan mahkota kecil, bangun bintang, berwarna ungu, benang sari berwarna kuning dengan jumlah 5 buah. Tangkai bunga berwarna hitam. Buah berbentuk bulat, berwarna hitam mengkilat sejak masih muda dan jika sudah tua diameter buahnya kira-kira 0,7 cm. Biji berbentuk bulat pipih, kecil-kecil, dan berwarna kuning (Gambar 1). Berdasarkan hasil identifikasi/ determinasi tumbuhan oleh "Herbarium Bogoriense" Bidang Botani Pusat Penelitian Biologi-LIPI Bogor, tanaman ranti hitam adalah jenis Solanum blumei Nees ex Blume, termasuk suku/famili Solanaceae dan telah disimpan dalam bentuk herbarium di "Herbarium Bogoriense" sejak Maret 2013.

Tanaman S. blumei Nees ex Blume sering digunakan masyarakat Dairi dan Karo sebagai tanaman obat tradisional sehingga berpotensi 
dikembangkan sebagai bahan baku obat. Tanaman obat umumnya mengandung senyawa bioaktif dalam bentuk metabolit sekunder seperti alkaloid, flavonoid, steroid, triterpenoid, tannin dan lain-lain yang dapat diekstraksi dengan berbagai pelarut berdasarkan tingkat kepolarannya. Hasil penelitian Sridhar et al., (2011), ekstrak buah Solanum nigrum L menunjukkan aktivitas penghambatan pertumbuhan bakteri tertinggi yang diikuti dengan ekstrak daun dan akar, sesuai dengan data konsentrasi penghambatan minimal (MIC).

Oleh karena itu penelitian kandungan metabolit sekunder dari ekstrak daun maupun buah tanaman obat ranti hitam (S. blumei Nees ex Blume) lokal ini perlu dilakukan sebagai dasar untuk mengembangkan potensinya sebagai bahan obat berbasis bahan alam. Pengembangan dan penelitian bahan obat berbasis tanaman ini sangat menguntungkan selain karena sumber bahan alamnya cukup tersedia, juga untuk mengatasi efek samping dan mahalnya harga dari penggunaan obat sintetik dan antibiotik.

\section{METODE}

\section{Bahan dan alat}

Alat yang digunakan adalah vacum rotary evaporator, corong Buchner, vortex mixer dan peralatan gelas (pyrex) yaitu corong pisah, labu erlenmeyer, labu ukur, batang pengaduk, pipet volume, tabung reaksi dan gelas ukur.

Bahan kimia yang digunakan adalah pelarut berderajat teknis untuk ektraksi meliputi $n$-hexana, etil asetat, etanol dan bahan kimia berderajat proanalis (p.a) (Merck) meliputi kloroform, eter, amil alkohol, asam asetat glasial, asam asetat anhidrat, asam sulfat (p), etanol 96\%, $\mathrm{NaOH}$, $\mathrm{HCl}, \mathrm{HNO}_{3}, \mathrm{Bi}\left(\mathrm{NO}_{3}\right)_{3}, \mathrm{HgCl}_{2}, \mathrm{KI}$, larutan ammonia $10 \%$, serbuk magnesium, $\mathrm{FeCl}_{3}$. Bahan tanaman yang digunakan adalah daun (hijau) dan buah ranti hitam (S. blumei Nees ex Blume) tua yang berwarna biru kehitaman, berasal dari desa Kuta Nangka, Kec. Tanah Pinem, Kabupaten Dairi. Sampel tanaman telah diidentifikasi oleh "Herbarium Bogoriense" bidang Botani Pusat Penelitian Biologi-LIPI Bogor).

Pereaksi Mayer: Sebanyak 1,359 g $\mathrm{HgCl}_{2}$ ditimbang, dilarutkan dalam air suling hingga $60 \mathrm{~mL}$. Pada wadah lain sebanyak $5 \mathrm{~g} \mathrm{KI}$ dilarutkan dalam $10 \mathrm{~mL}$ air suling. Kedua larutan dicampurkan lalu ditambahkan air suling hingga volume larutan $100 \mathrm{~mL}$ (Harborne,1996).

Pereaksi Dragendorff: Sebanyak 8,o g KI dilarutkan dalam $20 \mathrm{~mL}$ air suling (larutan 1). Sebanyak 0,85 g bismutnitrat dilarutkan dalam $2 \mathrm{~mL}$ air suling (larutan 2). Kedua larutan dicampurkan dan ditambahkan 7,0 $\mathrm{mL} \mathrm{HCl} \mathrm{(p)} \mathrm{dan} \mathrm{diencerkan} \mathrm{dengan} \mathrm{air} \mathrm{suling}$ hingga volume larutan $100 \mathrm{~mL}$ (Harborne,1996).

Pereaksi Lieberman Burchard: Sebanyak 5,o mL asam sulfat (p) dimasukkan ke dalam larutan $50 \mathrm{~mL}$ etanol 96\%, lalu ditambahkan 5,0 mL asam asetat anhidrat (Harborne, 1996).

\section{Ekstraksi tanaman}

Masing-masing daun dan buah S. blumei Nees ex Blume segar dicuci bersih, ditirskan, dikeringkan terhindar dari sinar matahari langsung dan digiling secara mekanik sampai menjadi serbuk simplisia. Masing-masing serbuk simplisia daun dan buah dimaserasi dengan pelarut yang bertingkat kepolarannya yaitu pelarut $n$-heksana, dilanjutkan dengan etil asetat dan diakhiri dengan pelarut etanol.Masing-masing serbuk simplisia daun dan buah dimaserasi dengan pelarut $n$ heksana, difiltrasi, filtrat dipekatkan pada rotari evaporator vacum sehingga diperoleh ekstrak $n$-heksana pekat. Selanjutnya ampas dimaserasi dengan pelarut etil asetat, difiltrasi, filtrat dipekatkan sehingga diperoleh ekstrak etil asetat pekat. Selanjutnya ampas dimaserasi kembali dengan pelarut etanol, difiltrasi, filtrat dipekatkan sehingga diperoleh ekstrak etanol pekat. Masing-masing proses maserasi tiap pelarut berlangsung selama 48 jam, dengan dua kali penambahan pelarut. Hasil ekstraksi diperoleh masing-masing ekstrak $n$-heksana, etil asetat dan etanol pekat dari daun dan buah tanaman ranti hitam.

\section{Uji fitokimia senyawa pada ekstrak daun dan buah ranti hitam \\ Uji fitokimia senyawa kimia pada ekstrak daun dan buah ranti hitam dilakukan sebagai berikut (Harborne, 1996):}

\section{Identifikasi golongan alkaloid}

Sebanyak 0,5 g ekstrak ditambah $5 \mathrm{~mL}$ asam klorida 10\%, dikocok dan ditambah 5 $\mathrm{mL}$ larutan amonia 10\%. Diekstraksi dengan $10 \mathrm{~mL}$ kloroform dan diuapkan. Residu sisa penguapan ditambah $1,5 \mathrm{~mL}$ asam klorida $2 \%$, dibagi dalam dua tabung. Tabung pertama 
ditambah 3 tetes pereaksi Mayer, terbentuknya endapan putih kekuningan menunjukkan adanya alkaloid. Tabung kedua ditambah 3 tetes pereaksi Dragendorff, terbentuknya endapan merah bata menunjuk-kan adanya alkaloid.

\section{Identifikasi golongan steroid dan triterpenoid \\ Sebanyak 0,5 g ekstrak diekstraksi} dengan $10 \mathrm{~mL}$ eter. Sebanyak 0,5 mL larutan diuji dengan pereaksi Lieberman Burchard. Terbentuknya warna biru atau hijau menunjukkan adanya steroid dan warna hijau atau ungu menunjukkan adanya triterpenoid.

\section{Identifikasi golongan flavonoid, saponin, tannin, dan kuinon}

Sebanyak 0,5 g ekstrak dilarutkan dalam $10 \mathrm{~mL}$ air dan diletakkan diatas penangas air, kemudian larutan tersebut dibagi menjadi empat tabung. Ke dalam tabung pertama ditambahkan $100 \mathrm{mg}$ serbuk magnesium lalu ditambah $1 \mathrm{~mL}$ asam klorida pekat dan $3 \mathrm{~mL}$ amil alkohol, dikocok kuat dan dibiarkan memisah, warna merah, kuning, jingga pada lapisan amil alkohol menunjukkan adanya flavonoid. Tabung kedua dikocok vertikal selama 10 detik, maka akan terbentuk busa stabil, dibiarkan selama 10 menit, ditambahkan 1 tetes asam klorida $1 \%$. Jika busa tidak hilang maka menunjukkan adanya saponin.Tabung ketiga ditambah beberapa tetes natrium hidroksida $1 \mathrm{~N}$, adanya filtrat warna merah menunjukkan adanya kuinon. Tabung keempat ditambah beberapa tetes larutan besi (III) klorida 1\%, terbentuknya filtrat warna biru tua atau hijau kehitaman menunjukkan adanya tanin.

\section{HASIL DAN PEMBAHASAN \\ Ekstraksi}

Pemilihan metode maserasi untuk proses ektraksi daun dan buah ranti hitam (S. blumei Nees ex Blume), selain berdasarkan efektifitas, praktis, keamanan, ekonomis, juga bertujuan untuk menghindari rusaknya senyawasenyawa aktif buah dan daun ranti hitam yang tidak tahan panas. Maserasi dilakukan dengan merendam masing-masing serbuk daun dan buah ranti hitam dalam pelarut selama 48 jam, dengan penambahan pelarut dua kali, kemudian pelarut dibebaskan dari ekstrak dengan menggunakan vacum rotari evaporator. Pemilihan pelarut pada proses maserasi berdasarkan pada prinsip kelarutan "like disolve like", artinya senyawa polar hanya larut dalam pelarut polar, begitu juga sebaliknya untuk senyawa-senyawa semipolar dan non polar. Pelarut yang digunakan pada penelitian ini untuk maserasi adalah mulai pelarut non polar sampai pelarut polar yaitu $n$-heksana, etil asetat dan etanol.Penggunaan berbagai jenis pelarut dengan berbeda tingkat kepolarannya dilakukan untuk memperoleh ekstrak dengan hasil optimal dari senyawa yang belum diketahui jenisnya. Rendemen ekstrak $n$-heksana, ekstrak etil asetat dan ekstrak etanol daun S.blumei Nees ex Blume, berturut-turut adalah 1,76\%; 3,17 \% dan 9,95\% (b/b). Rendemen ekstrak n-heksana, etil asetat dan ekstrak etanol buah $S$. blumei Ness ex Blume berturut-turut adalah 1,21\%; 2,50\% dan 4,09 \%(b/b) (Gambar 2).

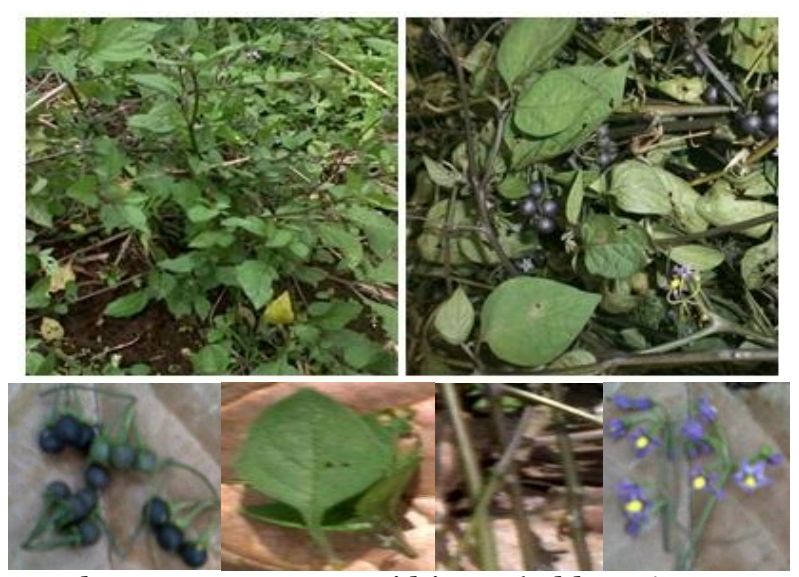

Gambar 1. Tanaman ranti hitam (S.blumei Ness ex Blume) dan bagiannya.

\section{Analisis fitokimia}

Analisis fitokimia merupakan salah satu cara untuk mengetahui kandungan metabolit sekunder pada suatu tanaman. Senyawa metabolit sekunder pada tanaman meliputi alkaloid, flavonoid, steroid dan triterpenoid, tanin dan lain-lain. Pada dasarnya senyawa metabolit sekunder ini bersifat toksik pada tumbuhan dan hewan. Pada sebagian tumbuhtumbuhan senyawa metabolit sekunder yang dihasilkan digunakan untuk mempertahankan diri dari musuh, tetapi pada dosis tertentu dapat digunakan sebagai obat. Hasil analisis fitokimia ekstrak daun dan buah $S$. blumei Nees ex Blume, disajikan pada Tabel 2.

Hasil analisis fitokimia metabolit sekunder, pada ekstrak heksana daun dan buah $S$. blumei Nees ex Blume sama-sama terdapat banyak steroid dan triterpenoid, lebih banyak fenol pada daun daripada buah dan sedikit alkaloid yang hanya terdapat pada 
ekstrak daun. Pada ekstrak etilasetat daun dan buah Solanum blumei Nees ex Blume, samasama terdapat banyak steroid dan triterpenoid, tetapi pada ekstrak etil asetat daun lebih banyak alkaloid, flavonoid, fenol dan tannin dibandingkan ekstrak buah.

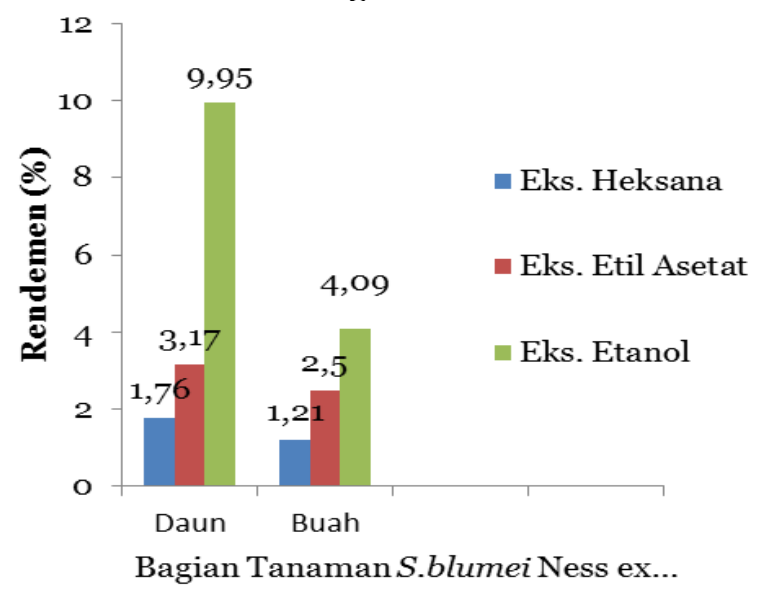

Gambar 2. Persentase rendemen ekstrak daun dan buah $S$. blumei Ness ex Blume.

Pada ekstrak etanol daun S. blumei Nees ex Blume lebih banyak terdapat flavonoid, alkaloid, saponin, kuinon, tannin, steroid dan triterpenoid dibandingkan pada ekstrak etanol buah. Pada ekstrak etanol buah tidak terdapat steroid, triterpenoid dan kuinon.

Alkaloid banyak terdapat pada ekstrak etanol daun $S$. blumei Nees ex Blume, diikuti ekstrak etanol buah dan etil asetat daun, sedangkan pada tanaman $S$. nigrum L, alkaloid banyak terdapat pada ekstrak etil asetat daun, etanol buah dan etil asetat buah (Sridhar et al., 2011). Flavonoid banyak terdapat pada ekstrak etanol daun, diikuti dengan ekstrak etanol buah dan ekstrak etil asetat daun $S$. blumei Nees ex Blume, sedangkan pada tanaman $S$. nigrum L, flavonoid selain banyak terdapat pada ekstrak etanol daun, juga terdapat pada ekstrak heksana buah (Sridhar et al., 2011). Fenol banyak terdapat pada eksrak etil asetat daun dan buah dan ekstrak heksana daun S. blumei Nees ex Blume, sedangkan pada S.nigrum L, fenol selain juga banyak terdapat pada ekstrak etil asetat daun dan buah, juga pada ekstrak nheksana buah (Sridhar et al., 2011). Steroid dan triterpenoid S. blumei Ness ex Blume banyak terdapat pada ekstrak $n$-heksana dan etil asetat daun dan buah, sedangkan pada $S$. nigrum L, steroid paling banyak terdapat pada ekstrak heksana buah, diikuti ekstrak etil asetat buah dan daun (Sridhar et al., 2011). Tanin lebih banyak terdapat pada ekstrak etanol daun, diikuti ekstrak etanol buah $S$. blumei Nees ex Blume, sedangkan pada $S$. nigrum $\mathrm{L}$ tanin terdapat pada ekstrak metanol daun dan etil asetat daun dan buah (Sridhar et al., 2011). Saponin banyak terdapat pada ekstrak etanol daun, diikuti ekstrak etanol buah $S$. blumei Ness ex Blume, sedangkan pada ekstrak heksana dan etil asetatnya tidak terdapat saponin, dan kuinon hanya terdapat pada ekstrak etanol daunnya.Gogoi dan Islam (2012), juga melaporkan bahwa hasil skrining fitokimia tanaman $S$. nigrum $\mathrm{L}$ dan $S$. myriacanthus Dunal dari daerah Upper Assam India menunjukkan kandungan metabolit sekunder yang berbeda.

Alkaloid dikatakan sebagai penanda taksonomi yang sangat baik oleh sejumlah peneliti. Kandungan alkaloid pada Solanum nigrum Complex adalah glikoalkaloid dan aglikon. Hasil penelitian Mohy-Ud-Din et al. (2010), berdasarkan kemotaksonomi kandungan glykoalkaloid dan aglyconnya, Solanum nigrum Complex terdiri dari lima taxa yaitu $S$. americanum Mill, $S$. chenopodioides Lam, $S$. nigrum. L, $S$. retroflexum Dunal dan $S$. villosum Mill. Glikoalkaloid pada tanaman Solanum nigrum Complex adalah Solasonine, a-Solamargine, $\beta$-Solamargine dan a-solanin dan aglyconenya (Solasodina dan Solanidine). Hasil penelitian Simorangkir et al., (2016), pada buah $S$. blumei Nees ex Blume terdapat senyawa alkaloid $\beta 2$-solanin [Solanid-5-ene$\left(1^{\prime} \rightarrow 3\right)-\beta$-D-glucopyranosyl-- $\left(1^{\prime \prime} \rightarrow 3\right)-\beta$ - $D$

galactopyranoside] dengan rumus molekul $\mathrm{C}_{39} \mathrm{H}_{63} \mathrm{NO}_{11}$ dan mempunyai aktivitas yang dapat menghambat pertumbuhan sel kanker leukimia L1210 dengan nilai $\mathrm{IC}_{50} \quad 1,2738$ $\mu \mathrm{g} / \mathrm{mL}$ (Simorangkir, et al., 2014).

Beberapa hasil penelitian melaporkan bahwa metabolit sekunder alkaloid, flavonoid, steroid, tanin, saponin, fenol yang terdapat pada tanaman mempunyai berbagai aktifitas biologis/obat (Akubugwo et al., 2007; Haniffa et al., 2011; Sridhar et al., 2011; Prima dan Raditya, 2011). Oleh karena itu berdasarkan hasil penelitian metabolit sekunder yang telah dilakukan, tanaman S. blumei Nees ex Blume lokal mempunyai potensi untuk dikembangkan sebagai bahan alam yang mempunyai berbagai aktifitas biologis/obat. 
Tabel 2. Analisis fitokimia ekstrak daun dan buah $S$. blumei Ness ex Blume.

\begin{tabular}{|c|c|c|c|c|c|c|c|c|}
\hline \multirow[t]{2}{*}{ Jenis Ekstrak } & \multicolumn{8}{|c|}{ Jenis Metabolit Sekunder } \\
\hline & Alkaloid & Steroid & Triterpenoid & Flavonoid & Fenol & Saponin & Kuinon & Tannin \\
\hline Daun & & & & & & & & \\
\hline Heksan & + & +++ & +++ & - & +++ & - & - & - \\
\hline Etil Asetat & ++ & +++ & +++ & ++ & +++ & - & - & + \\
\hline $\begin{array}{l}\text { Etanol } \\
\text { Buah }\end{array}$ & +++ & ++ & ++ & +++ & + & +++ & + & +++ \\
\hline Heksan & - & +++ & +++ & - & + & - & - & - \\
\hline Etil Asetat & ++ & +++ & +++ & + & +++ & - & - & + \\
\hline Etanol & ++ & - & - & ++ & ++ & ++ & - & ++ \\
\hline
\end{tabular}

\section{KESIMPULAN}

Melalui proses maserasi daun dan buah Solanum blumei Nees ex Blume dengan menggunakan pelarut bertingkat kepolarannya, diperoleh rendeman yang paling tinggi adalah ekstrak etanol daun $(9,95 \% \mathrm{~b} / \mathrm{b})$ dan buah $(4,09 \% \mathrm{~b} / \mathrm{b})$, diikuti dengan ekstrak etil asetat daun $(3,17 \% \mathrm{~b} / \mathrm{b})$ dan buah $(2,50 \% \mathrm{~b} / \mathrm{b})$ dan ekstrak $n$-heksana daun $(1,76 \% \mathrm{~b} / \mathrm{b})$ dan buah $(1,21 \% \mathrm{~b} / \mathrm{b})$. Hasil analisis fitokimia menunjukkan bahwa, ekstrak S. blumei Nees ex Blume mengandung metabolit sekunder alkaloid, flavonoid, tannin dan saponin yang lebih banyak terdapat pada ekstrak etanol daun daripada ekstrak etanol buah. Kuinon hanya terdapat pada ekstrak etanol daun. Fenol banyak terdapat pada eksrak etil asetat daun dan buah. Steroid dan triterpenoid banyak terdapat pada ekstrak nheksana dan etil asetat daun dan buah serta dalam ekstrak etanol daun.

\section{DAFTAR PUSTAKA}

Akubugwo, O., \& Ginika. (2008). Mineral and phytochemical contents in leaves of Amaranthus hybridus L and Solanum nigrum L. subjected to different processing methods. African journal of biochemistry research, 2(2):040-044.

Gogoi, P., \& Islam, M. (2012). Phytochemical screening of Solanum nigrum $\mathrm{L}$ and $S$. Myriacanthus Dunal from districts of upper assam. India, IOSR Journal of pharmacy, 2(3): 455-459.

Haniffa, D., \& Dhanuskodi. (2011).Evaluation of immunostimulant potensial of Solanum nigrum L using fish, Etroplus suratensis challenged with Aphanomyces invadens. International journal of pharma and bio sciences, 2(1):B429B435.

Harborne, J. B. (1996), Metoda fitokimia, penuntun cara modern menganalisa tumbuhan, ITB, Bandung.

Mohy-Ud-Din, A.K., Ahmad, M., \& Kahmiri, M.A. (2010). Chemotaxonomic value of alkaloids in Solanum nigrum complex. Pakistan journal of botany, 42(1):653660.

Prima, I., \& Raditya. (2012), CRC Farmasi UGM-Leunca (Solanum nigrum L.) http://www.ccrc.farmasi.ugm.ac.id/?page id=2339, diakses tanggal 24/03/2012.

Simorangkir, M., Surbakti, R., Barus,T. \& Simanjuntak, P. (2014). Inhibitory activity of alkaloid of extract ethanol ranti hitam (Solanum blumei Nees ex Blume) fruit on leukimia L1210 cancer cells growth, Proc. $1^{\text {th }}$ International Seminar on Trends in Science and Science Education ,ed.M, Situmorang \& H. Sipahutar. State University of Medan, pp120-126.

Simorangkir, M., Barus, T., Surbakti, R. \& Simanjuntak, P. (2016). Isolation and toxicity of steroidal alkaloid glycoside from fruits of ranti hitam (Solanum blumei Nees ex Blume). Asian journal of chemistry, 28(1):203-206.

Sridhar,T.M., Josthna,P., \& Naidu, C.V. (2011). In vitro antibacterial activity and phytochemical analysis of Solanum nigrum (Linn.)-An important antiulcer medicinal plant. Journal of experimental sciences, 2(8): 24-29. 